\title{
The Detective as Midwife in Dostoevsky's Crime and Punishment
}

\author{
Vladimir Golstein
}

It is easier to write about Socrates than about a young lady or a cook.

-Chekhov, in his Jan 2, 1894, letter to Suvorin

Truth is the daughter of Time, and I feel no shame in being her midwife.

-Johannes Kepler

When, in the final chapter of Crime and Punishment, Raskolnikov climbs the stairs and arrives at the police station to confess, he encounters a tipsy police lieutenant, Ilya Petrovich, who launches—quite unexpectedly—into an attack on nihilists and ... midwives:

\footnotetext{
"There are such a lot of nihilists now, all over the place, and indeed it is easy to understand why, what times these are, I ask you. You and I, however ... of course, you aren't a nihilist, are you? ... You can be open with me, you needn't hesitate... There are an extraordinary number of midwives cropping up all over the place."-Raskolnikov raised his eyebrows questioningly ..."I am talking of those short-haired females,"-went on the garrulous Ilya Petrovich. "It is my own idea to call them midwives and I think the name is very satisfactory ... They push themselves into the Academy and study anatomy; well, tell me, if I fall ill am I going to call in a girl to cure me? He,
} 
he!” Ilya Petrovich laughed, delighted with his own wit ... “Then again, look what a lot of these suicides there are: you can't imagine ... Why, only this morning we had the case reported to us of a gentleman newly arrived in St. Petersburg. Nil Pavlovich, what was his name?”... "Svidrigailov!” answered a hoarse voice. ... Raskolnikov started. $(447-48)^{1}$

This somewhat humorous passage is clearly pregnant with meanings that only a good midwife can deliver. Ilya Petrovich's references to the new fashion of female education and the new trends of emancipation should not obscure the fundamental fact that the profession chosen by female radicals, besides its medico-scientific dimension, is deeply steeped in myths, history, and cultural tradition. Various cultures, Russia's included, imagined a midwife as a particular type of woman, capable of functioning at the cross-section of biological and spiritual, medical and religious. In the spirit of this cross-section, a midwife was expected to be some sort of a mediator (as the English word "midwife" clearly implies). Likewise, midwives were expected to be postmenopausal women, preferably widows not engaged in erotic activity, as if their sexuality and ability to conceive would hinder their ability to deliver somebody else's children. Consequently, we can understand the tension that Russian society experienced at the time of Crime and Punishment, the tension that the Russian language clearly captures: traditional midwives were called povival'niye babki, while younger girls who preferred the medical and scientific approach to the issue wanted to be known by the French variant of the term, akusherka [акушерка]" ("obstetrician"). The very term babka, of course, suggests a grandma, hardly a proper name for a young educated girl. Dostoevsky's own novel The Demons features Shatov's pregnant wife requesting the help of a cheaper, older peasant midwife, but she is persuaded to employ the young radical akusherka, Virginskaya.

Besides elaborating the tension of old and new, Ilya Petrovich's diatribe inadvertently describes emerging cultural trends that Dostoevsky had always been ready to observe and discuss, such as nihilism, scientism, and suicide.

1 All references to Dostoevsky are to the Polnoe sobranie sochinenii v tridsati tomakh [PSS], ed. V. G. Bazanov et al. (Leningrad: Nauka, 1972-90); hereafter cited as PSS by volume and page. I have relied on the English translation of the novel in Crime and Punishment, 3rd ed., Norton Critical Edition, ed. George Gibian, trans. Jessie Coulson (New York: Norton, 1989). The page number is given in parenthesis following the quotation itself. All other translations are my own. 
Thus, his Diary of a Writer pays special attention to the suicide of a young radical woman, named Pisareva, who got her medical education as a midwife. The fictional variant of this interlink of deaths, suicides, and midwives is elaborated on the pages of The Demons, where Dostoevsky demonstrates how well aware he was of the cultural expectations connected with midwifery; the radicalism of the young nihilistic women (Virginskaya, or Shatov's sister, Darya) is underscored by the fact that they combine erotic affairs and midwifery. ${ }^{2}$

But leaving Dostoevsky's own preoccupation with radical youth aside, what is interesting about Ilya Petrovich's diatribe is that it captures the new reality that the novel depicts. The times are different, and they produce new cultural types: nihilists and feminists. The traditional old woman in a village is replaced by a short-haired, educated, gentry girl; the traditional violent murderer (a character in the novel's epilogue insists that "it is not a nobleman's job to kill with an ax") is replaced with an intellectual student; the traditional pleasure seeker and seducer, Svidrigailov, is replaced with a Nietzschean superman bound on suicide.

Ilya Petrovich's comical claim about the "overabundance of midwives" and other nihilists - implying a new reality that the novel captures-highlights another important dimension of Dostoevsky's text: practically all the novel's characters (ranging from Marmeladov and Sonya to Svidrigailov and Luzhin) function as midwives, as people who help Raskolnikov to deliver his confession, to undergo his spiritual rebirth.

Images of birth and delivery accompany Raskolnikov from the beginning to the end of the novel. Thus, the very first sentence announces the process of emerging - mostly metaphorically, but with the sufficient stress on the physical activity: "Toward the end of a sultry afternoon in July a young man came out of his little room" (1). The physical movement of Raskolnikov prefigures not only the miraculous image of Lazarus coming out of his grave but also a rather mundane thing, such as the birth of a child. A few chapters later, we hear Nastya's comment on Raskolnikov's nightmare, in which Ilya Petrovich appears to be beating Raskolnikov's landlady: "It is your blood that makes a noise. It's when it hasn't got an outlet, and it begins to get all clotted, and then you begin to get visions" (99). In connection with this search for outlet, it is worth

2 Cf. Muireann Maguire, "Dostoevsky and the Politics of Parturition: Childbirth as Political Motif in Demons," Modern Language Open 1 (2014): 1-9. 
remembering Porfiry Petrovich's own incessant reminder to Raskolnikov that the latter needs "air," an open space, an outlet. Likewise, in the epilogue to the novel, we encounter the reference to the nine-month gestation period, when we read of Raskolnikov's mother yearning for her son: "One morning she roundly declared that by her reckoning Rodya ought soon to be with them, and that she remembered his telling her ... that they must expect him in nine months" (именно через девять месяцев) (456).

The key role in this process of Raskolnikov's delivery, however, is played by Porfiry Petrovich, a character embodying a new type of a detective. A traditional policeman, a dogged pursuer of the criminal would not do in this novel of new types. It is my claim that Porfiry Petrovich is this strange combination of old and new, of pursuer and pursued, of nihilist and midwife, of a person who upholds the law, yet operates outside it. In other words, the reversals and paradoxes of various gender and cultural roles, to which Ilya Petrovich alludes so boldly, have also touched upon Porfiry.

For attentive readers, Porfiry Petrovich does appear as an uncanny figure, as someone who is less of a character and more of a device. Thus R. P. Blackmur claimed that Porfiry is an unreal character, serving as an agency of the plot, something "to make the wheels go round." 3 Joseph Frank elaborates the point in the following manner: "Unlike Poe's Dupin, he is far from being a monster of rationality; nor is he, like Hugo's Javert, a relentless incarnation of the Law. ... Porfiry's role-playing is very much like that of a novelist, who embodies his own personality in a whole range of characters." In terms of "embodying a whole range of characters," Porfiry should remind us of a well-known (reallife) nineteenth-century detective, Eugène-François Vidocq-one of the founders of modern criminology and a precursor of the comic Inspector Clouseau - who was notorious for his ability to assume different personalities when in pursuit of his suspects. Yet, what is important about Porfiry's shifty character is not so much his ability to camouflage himself into different masks, but rather his own protean nature, which connects him to another intellectual investigator known since the time of antiquity.

3 Edward Wasiolek, ed. and trans., Notebooks for "Crime and Punishment" (Chicago: University of Chicago Press, 1967), 132.

4 Joseph Frank, Dostoevsky: The Miraculous Years 1865-1871 (Princeton, NJ: Princeton University Press, 1995), 125. 
I refer to Socrates, of course, a brilliant and versatile thinker, who compared his own intellectual pursuit of truth to the art of midwifery while claiming that his purpose was to bring forth what's latent in his students. ${ }^{5}$ Indeed, besides its obvious medical side, the art of midwifery — at least since the time of Socratesimplied psychological, philosophical, and aesthetic dimensions: to bring forth, to facilitate and trigger inner transformation and rebirth. That aspect of Socrates has been the subject of scrutiny of various scholars, including the recent studies by Myles Burnyeat and Radcliffe Edmonds.

Besides the similarities in appearance (short, stout, paunchy, snubnosed, large round head) or dress (both were frequently seen in what looks like robes, or the Russian khalat), Porfiry Petrovich and Socrates share goals (to bring forth the beautiful inner person) and methods. They both are forever ironic, meta-literary, and ready to deconstruct, expose, and scrutinize their own methods, while skillfully using verbal traps and other rhetorical tricks of the trade. Their complex verbal strategy stems from the fact that even though they are clearly more skillful than sophists in one case, or detectives in another, their purpose is not to win an argument or capture a criminal, but rather to produce change in their interlocutors, to bring forth justice, temperance, truth, and other qualities that were hidden before their interference.

Similar to Socrates's role vis-à-vis his interlocutors, Porfiry doesn't simply want to catch Raskolnikov, he wants to bring forth a transformation and change in consciousness. Dostoevsky — writing at the time of the novel_formulated his ideas on change in the following manner: "Man is not born for happiness ... because the knowledge of life and consciousness ... is acquired by experience pro and contra, which one must take upon oneself. (By suffering, such is the law of our planet, but this immediate awareness, experienced through the life process,

5 The fact that a number of Crime and Punishment's characters function as Socratic midwives has been observed by M. W. Russell, "Beyond the Will: Humiliation as Christian Necessity in Crime and Punishment," in Bloom's Modern Critical Interpretations: Fyodor Dostoevsky's Crime And Punishment, ed. with an introduction by Harold Bloom (New York: Chelsey Publishing House, 2004). Russell states, "Of course Dostoevsky is ... recalling that Socrates described himself as a midwife in Plato's Symposium. As the wise woman from Mantinea, Diotima, helped Socrates bring forth his soul in beauty and reach Sophia or wisdom, so Sonya serves as a midwife for the soul of Raskolnikov, even as a spiritual physician who helps cure him of his madness" (240). 
is such a great joy that one gladly pays with years of suffering for it.)" ${ }^{\prime 6}$ In other words, Dostoevsky views suffering as "labor," as the process required for the birth of new awareness. By referring to "the law of our planet," Dostoevsky clearly invokes the verdict of the Almighty, who associated earthly gains with the pain of labor: "In sorrow thou shalt bring forth children ... in the sweat of thy face shalt thou eat bread" (Gen. 3:16-18).

Porfiry Petrovich, a police investigator in search of the pawnbroker's murderer, is entrusted with helping Raskolnikov with all kinds of deliveries. Raskolnikov's first labor is clearly connected with his guilt and confession. As many criminals before or after him, Raskolnikov is suffering from the "compulsion to confess," an affliction known in literature at least since Chaucer, "Murder will out - that see we day by day," and Shakespeare, "Foul deeds will rise / Though all the earth o'erwhelm them, to men's eyes,"7 and studied in detail by German psychiatrist and great admirer of Dostoevsky, Theodor Riek. ${ }^{8}$ Raskolnikov's guilt surely wants out, and it forces him to act stupidly in front of Zametov, as he does when he revisits the scene of the crime. By the way, this scene of revisiting the pawnbroker's apartment is the longest chapter of the novel (eighteen pages; pt. 2, ch. 6), only approximated by the scene describing one of Raskolnikov confrontations with Porfiry (seventeen pages; pt. 3, ch. 5). The length and the tortuous content of these chapters clearly invoke the images of labor.

It is hardly surprising, therefore, that during this scene of revisiting the pawnbroker's apartment, Raskolnikov encounters another strange "midwife" figure-a mysterious man who eventually accuses him of crime. This stranger is described as a classic Russian "midwife" (povival'naya babka): "A little man who looked like a superior workman or small tradesman, but since he was wearing a sort of long robe (khalat) and a waistcoat, from a distance he resembled a peasant woman ... His whole figure seemed to stoop. From his flabby wrinkled face he seemed to be over fifty; his sunken little eyes looked hard, morose, and discontent" (230). This female-like tradesman will appear again, during another labor scene with Porfiry when Porfiry hides the man in a closet with the purpose

6 PSS, 7:154-5.

7 Geoffrey Chaucer, “The Nun's Priest's Tale," in The Canterbury Tales, line 15,058; and Shakespeare, Hamlet, 1.2.256-57 (act, scene, lines).

8 See Theodore Riek, The Compulsion to Confess: On the Psychoanalysis of Crime and Punishment (New York: Farrar, Straus and Cudahy, 1959). 
of surprising and eliciting Raskolnikov's confession. This time the connection between Porfiry and his double, the tradesman, is made blatantly clear:

Porfiry Petrovich was informally dressed, in a dressing gown (khalat) and slippers trodden down at the heel ... He was a man of about thirty-five, rather short and stout, and somewhat paunchy. He was clean-shaven, and the hair was cropped close on his large round head, which bulged out at the back... His fat, round rather snub-nosed, dark skinned face had an unhealthy yellowish pallor, and a cheerful slightly mocking expression. It would have seemed good-natured were it not for the expression of his eyes ... The glance of those eyes was strangely out of keeping with his squat figure, almost like a peasant woman's. (211)

Socrates's remarkable appearance is well known from Plato and other contemporary works, such as Xenophon's Symposium and Aristophanes's Clouds. ${ }^{9} \mathrm{He}$ is described as rather ugly with a snub, broad nose, piercing eyes, and a wide mouth. He wore a simple, unadorned robe-like garment (himation) wrapped about his pot-bellied body.

It is worth stressing that Socrates's appearance-besides leaving its mark on both Porfiry and the tradesman-invokes that of Dostoevsky himself. According to the memoirs of Dr. Yanovsky, a close friend of Dostoevsky, "His wide forehead and round head, and wide put eyes made his head look like that of Socrates. He was very proud of this similarity." ${ }^{10}$ Likewise, A. N. Maikov, describing the early, Petrashevsky period of Dostoevsky, wrote that he remembers Dostoevsky, in the manner of dying Socrates, in a nightgown, delivering speeches to his friends about the sacred task of saving the motherland. ${ }^{11}$

Judging by drafts of the novel, Porfiry was initially presented as a rather realistic figure with various concrete details relating to his life and his professional activity. Yet, even this realistic figure had a rather metaphorical and suggestive last name-Semenov, ${ }^{12}$ referring to the seed (semia): a potent

9 Plato, Symposium 215a-c, 216c-d, 221d-e (566-67, 572), and Theaetetus 143e (848). Translations, and page numbers in parentheses, are taken from Plato, The Collected Dialogues, ed. Edith Hamilton and Huntington Cairns (Princeton, NJ: Princeton University Press, 1961).

10 O. V. Marchenko, "Sokraticheskaya tema u Dostoevskogo," in Istoriko-filosofskii ezhegodnik: 2001 (Moscow: Nauka, 2003), 155.

11 PSS, 18:192.

12 PSS, 7:68. At another moment Porfiry is called Porfiry Semenovich (PSS, 7:166). 
image of birth and transformation in the universe of Dostoevsky, as the very epigraph to The Brothers Karamazov suggests. Despite the symbolism suggested by Porfiry's last name, he is presented in the drafts as a rather realistic detective, who hesitantly gropes for the truth, as he circles around Raskolnikov and interrogates Raskolnikov's friends. In the final version of the novel, however, we encounter a rather different Porfiry: a person who is not so much an investigator as he is a spiritual guide. In this respect, it is highly relevant to recall Father Tikhon from Dostoevsky's later novel The Demons - whose probing psychological questions provoke the following response from Stavrogin: "The monk would have made the greatest police investigator." ${ }^{13}$ Stavrogin's comment clearly foreshadows G. K. Chesterton's famous detective, Father Brown.

This ease with which a monk in Dostoevsky's world can become a police investigator explains why Porfiry-as Dostoevsky's work on Crime and Punishment continues-became more symbolic, more Socrates-like, anticipating future characters such as Father Tikhon or even Father Zosima, whose role as a spiritual midwife has been revealed in his encounter with another murdererthe so-called mysterious visitor in Brothers Karamazov.

It is clear that to accomplish his roles of spiritual guide, midwife, and police investigator, Porfiry has to be a rather oxymoronic figure, the figure that embraces all possible contradictions. Despite his "official status," Porfiry appears to be strangely uprooted. There is nothing that will tie him to something particularly human or concrete. He lives in a "state-owned apartment," even though in the drafts he was supposed to rent from Lebezyatnikov; ${ }^{14}$ he does not have a family name-a rare instance in the world of Dostoevsky; he has a peculiar sexuality: we learn that now he wants to join the monastery, now prepares to get married. In that respect, Porfiry Petrovich cuts a figure similar to Prince Myshkin or Kalganov.

According to Socrates's modus operandi, it is precisely his "wide nature"- to borrow Dostoevsky's term - that enables him to succeed in bringing new truths into the world. His feigned ignorance, his strength and endurance hidden behind clumsiness, his rhetorical prowess hidden behind deliberately crass language are well-known features. On that level, Socrates has a long list of heirs in various cultural traditions, including holy fools (yurodivye) of Russian tradition.

13 PSS, 12:110.

14 PSS, 7:186. 
This protean or Socratic nature of Porfiry makes the discussion of his character difficult. Unless we create some sort of equivalent Socratic discourse, we are bound to reduce and impoverish him. The part of this discourse should stress the radical difference between Porfiry and the rest of the characters, the same difference that characterizes Socrates and his follows or opponents. In articulating his superman idea, Raskolnikov frequently refers not just to Napoleon but also to the ancient Greek figures of Lycurgus and Solon, whoin a radical difference from the historical Socrates-relied on coercive state power to accomplish their goals. Socrates, on the other hand, insisted that radical reform can and should be secured through persuasion alone. And that's the path that Porfiry also strives to follow.

It is also worth stressing that the ability to dwell in all possible domains is what gives great fictional detectives their insights into crime. They all tend to act like Socrates. As in the case of traditional midwives who succeeded at their trade only after they moved beyond a well- defined sexual role, there exists a conviction that the lack of concrete identity, be it social, sexual, or any other is what enables these characters to solve their mysteries. From Sherlock Holmes to the heroes of Agatha Christie, to Chesterton's Father Brown, to TV's Columbo with his ever-absent wife, we see the strange correlation between their insights into criminals and diffused identity and sexuality. ${ }^{15}$

In fact, Socrates's failure to pay attention to erotic advances is a feature frequently commented on in Plato's dialogues. Socrates is much more interested in his role as a tutor or mentor than as a lover-for all his charm and tricks, Alcibiades, for example, fails to get Socrates to bed. ${ }^{16}$ In Theaetetus, Socrates is quite articulate about his function as an intellectual and moral midwife: "I am childless in such things, and I am only trying to assist in the birthing, and to that end uttering charms over you and serving up things from each of the wise for you to task, until I bring out with you into the light your own belief." He also reminds us that Greek tradition also expected midwives to abstain from procreation themselves: "You know ... that women never practice as midwives while they are still conceiving and bearing children themselves. It is only those who are past child bearing who take this up." ${ }^{17}$

15 Christopher Wallace, “The Case of the Celibate Detective," Salon.com, accessed January 21, 2016, http://www.salon.com/2013/02/03/the_case_of_the_celibate_detectives/.

16 Symposium $219 \mathrm{~b}-\mathrm{d}(570)$.

17 Symposium $149 \mathrm{~b}(854)$. 
This line of reasoning is worth elaborating, since it suggests a rather complex process behind various transformations of Dostoevsky's characters. In the Symposium, Plato depicts his teacher not as the progenitor or begetter of ideas, but as Socrates the Beautiful, who assists as a midwife at the labor of the fertile young men, helping them bring their spiritual progeny to light. It is a young man (a lover) who is already pregnant by virtue of his stage in life who now gives birth assisted by the object of his admiration (the beloved one). Radcliffe Edmonds explains the process in the following way:

The entire process of procreation takes place within the lover: arousal, begetting, pregnancy and parturition ... Diotima describes the lover as a young man in search of beauty to relieve his pregnant soul. This lover is in search of the beloved who is possessed of beauty, at least in his soul ... and the presence of this beloved allows the lover to bring to birth the spiritual progeny with which he is in travail. Or in the words of the "Symposium": "whenever something pregnant draws near to beauty, it becomes glad and rejoicing, it lets and begets and gives birth.... Hence, for the one who is pregnant and already swelling, there is much excitement about the beautiful because of the possibility of relieving the enormous labor pains. ${ }^{18}$

The object of veneration, the beloved, for Plato, acts as a midwife, as someone who brings forth the progeny that the lover has been carrying for a long term ... It is through the contact with the beauty of his beloved that the admirer (the lover) is delivered of his pregnancy. Beauty thus works as a midwife; it is this instrument that - in the words of Socrates - "utters charms" upon the soul and brings forth the progeny. ${ }^{19}$

18 Radcliff G. Edmonds III, "Socrates the Beautiful: Role Reversal and Midwifery in Plato's Symposium," Transactions of the American Philological Association 130 (2000): 266-67.

19 Dostoevsky's musings on the beauty that should save the world acquire new urgency and new understanding once we consider the role of beauty in the process of delivery. "The world would become Christ's beauty” (Мир станет красота Христова), Dostoevsky observed in his drafts for The Demons (PSS, 11:188). The beauty of Christ, of his image and actions, brings forth the best in us and in the world. Consequently, Porfiry can be connected to porfira ("purple"), the beautiful color associated with regal power and glory. Dostoevsky, who viewed beauty as something truly redeeming, had to share this Socratic sensitivity. In other words, it is not just Socratic dialogue or Socratic intellectual provocations that produced the necessary changes in the subject, but rather something more mysterious, akin to the skills of traditional midwives who-while working at the cross-section of medicine and religion-would charm the soul into delivery. Seen from this perspective, Porfiry's vague, submerged sexual interests imply a 
Porfiry's purpose is not just to catch Raskolnikov, and not just to debunk him by challenging his intellectual, emotional, and moral defenses, but rather to facilitate the rebirth of a new man, a new Raskolnikov. It is hardly a coincidence that from the very first interview, Porfiry makes Raskolnikov focus on such images of transformation as Lazarus's resurrection or the New Jerusalem.

Unexpected as the roles of a spiritual guide and midwife are for a police investigator, it is this trajectory that Porfiry travels. In the process of investigation, Porfiry understands what kind of a criminal he is dealing with. He keeps on praising Raskolnikov's heart, soul, and nobility. Consequently, he understands that Raskolnikov's crime is not just of a legal but also of an ideological and moral nature. So it is Raskolnikov's ideology that has to be defeated, and it is Raskolnikov himself who has to acknowledge his defeat. Only then can the transformation begin. Spiritual progress can be achieved only after genuine remorse and attrition. Porfiry thus facilitates the birth of the new self, the "rebirth" of Raskolnikov, or rather of these aspects of Raskolnikov that the latter has tried to suppress and cut out.

On Raskolnikov's moral and spiritual "pregnancy," Dostoevsky observed, "His moral development begins with the crime itself. The very possibility of such questions did not exist before. In the last chapter, in prison, he said that without this crime, he would not have confronted such questions, desires, feelings, needs, strivings, and development." ${ }^{20}$

Porfiry plays the central part in the process of Raskolnikov's transformation, as he tries to disarm Raskolnikov ideologically and encourage him to reverse the trajectory of his thoughts. Porfiry as a police detective has to disappear, giving place to a spiritual midwife. Let us trace this trajectory as it is revealed in their three interviews.

The first interview starts on a Gogolian note, as Porfiry appears on the stage quoting a well-known line from Gogol's Inspector General. This early reference to Gogol's play sets the tone for what's to follow: it introduces theatrical terms and the very concept of play-acting so relevant to both Porfiry, who wants to trick Raskolnikov, and to Raskolnikov, who pretends to be innocent. Furthermore, Gogol intended his play as a vehicle "to catch the conscience of Russia,"

person whose sexuality has been transcended and transformed into inner beauty that serves as a magnet for the spiritual beauty of Raskolnikov.

20 Wasiolek, Notebooks for "Crime and Punishment," 11. 
to make it undergo self-scrutiny and consequent transformation. This ability of the theater to induce moral transformation by making the criminal confess has been known at least since the time of Shakespeare:

I have heard that guilty creatures sitting at a play

Have, by the very cunning of the scene,

Been struck so to the soul that presently

They have proclaimed their malefactions.

For murder, though it have no tongue, will speak

With most miraculous organ....

... The play's the thing

Wherein I'll catch the conscience of the king.

(Hamlet, 2.2.575-580; 591-92)

Dostoevsky, who knew Gogol practically by heart, was clearly aware of both literal and metaphorical meanings of Gogol's famous comedy. So it is hardly surprising that Porfiry is presented as a Gogolian figure who intends to disarm, catch, and transform Raskolnikov.

Besides its theatrical underpinnings, the first dialogue between Porfiry and Raskolnikov also has features of a Platonic dialogue. Besides Porfiry and Raskolnikov, several other people are present in Porfiry's apartment (Razumikhin and Zametov), and the gathering has the elements of some kind of a soiree or symposium. The participants discuss the nature of the crime, socialism's view of it, the role and impact of the environment. The discussion eventually focuses on the exchange between Porfiry and Raskolnikov as the former begins to question Raskolnikov's theory. He subjects it to ironic taunting, takes extreme extrapolations from his theory, and personalizes the debate by forcing Raskolnikov to personalize his abstract theory. Porfiry concludes their conversation with an intellectual trap for Raskolnikov (asking him about the details of the crime scene), which Raskolnikov skillfully avoids. In other words, following the illustrious examples of Plato, Shakespeare, and Gogol, Porfiry wants to capture Raskolnikov through some sort of verbal trap. Or to be more precise: the elements of Gogol's play skillfully hide Porfiry's own art, his Socratic attack on Raskolnikov's reason, and his intellectual defenses.

The second dialogue between the Porfiry and Raskolnikov presents their confrontation in a different key, as it becomes more focused on the technical aspects of crime and investigation. The action moves into Porfiry's office, and 
the conversation becomes less intellectual and abstract as it focuses on human nature and its failures to act according to logic. Instead of Raskolnikov's theories, the two discuss the behavior of a criminal and the detective strategies of capturing him. Rather than setting up an intellectual trap, Porfiry tries to provoke Raskolnikov into confession. He works on Raskolnikov's emotional defenses and uses everything in his repertoire to mock and tease him. Porfiry skillfully mixes criminal themes with his banter on gymnastics, hemorrhoids, and other health issues (258): "He was dropping empty phrases, frequently falling into nonsense" (260). At one moment, the detective is described as a ball bouncing from one wall into another (256); at another, Porfiry's laughing body is compared to a rubber eraser, suggesting the lack of a definitive shape (257).

In a complex irony fitting of Socrates, Porfiry attacks the formalism of various police methods. "The form is nonsense," he pronounces, while asserting that "one cannot restrict the investigator with the form, he is a free artist" (260). A protean, free artist, a figure capable of being simultaneously everywhere and nowhere, not only implies a policeman whose net is spread wide, but more importantly, it takes us back to the very essence of Socrates, who in his paradoxical exchanges has also proven to be nowhere and everywhere, knowing all and nothing. Even in his manner of conversation, Porfiry is similar to Socrates, as both are very good at switching the tone, using all possible verbal registers, ranging from banter to philosophical moralizing. In fact, Porfiry's language is by far more rich and diverse than that of any other character in the novel. Not just physically, but verbally, Porfiry manages to be nothing and everything, creating thus a net to catch Raskolnikov.

This discussion, as it focuses on the psychological state of the criminal, raises issues pertinent to Porfiry's midwife function. As Porfiry talks about "catching the criminal," he discusses the revolt of the criminal's human nature, the revolt that "ripens" the criminal, prepares him for confession. "Why should I bother him before his due time [do sroka]," he admits (260). This concept of ripening toward the allotted date suggests, of course, the time of pregnancy. The combination of guilt, uncertainty, and suspense forces the criminal into confession, but only after a period of time needed for gestation, without which no midwife is able to deliver. Furthermore, Porfiry discusses aesthetic issues during this dialogue, implying the role of beauty needed in this process of gestation. 
In this interview, Porfiry reminds us that he has other fish to catch besides the criminal. He keeps returning to the concept of "higher mission" for which Raskolnikov is destined - in contrast to Porfiry himself: "I am a bachelor, I am a finished man, I went to seed" ( $v$ semia poshel) (257). While pointing to the contrast between the "finished" Porfiry and the younger Raskolnikov, Porfiry's comment is deliberately contradictory and paradoxical. How can a bachelor "go to seed"-an expression usually applied to the family man with children - unless it is the loner who is in the business of delivering other people's seed. Porfiry clearly uses the term metaphorically: he refers to the "children" that he has delivered, that is, to the criminals whose spirit he helped to resurrect by bringing them back to God.

Porfiry's rhetoric finds its perfect equivalent in Socrates's claims that he is nothing but a midwife, a person incapable of giving birth to wisdom, but capable of helping others to deliver "the admirable truths" that have been hidden within them. Socrates is rather articulate about the nuances of his skill:

My art of midwifery is in general like theirs [real midwives]; the only difference is that my patients are men, not women, and my concern is not with the body but with the soul that is in travail of birth. And the highest point of my art is the power to prove by every test whether the offspring of a young man's thought is a false phantom or instinct with life and truth. I am so far like the midwife that I cannot myself give birth to wisdom, and the common reproach is true, that, though I question others, I can myself bring nothing to light because there is no wisdom in me. The reason is this. Heaven constrains me to serve as a midwife, but has debarred me from giving birth. So of myself I have no sort of wisdom, nor has any discovery ever been born to me as the child of my soul. Those who frequent my company at first appear, some of them, quite unintelligent, but, as we go further with our discussions, all who are favored by heaven make progress at a rate that seems surprising to others as well as to themselves, although it is clear that they have never learned anything from me. The many admirable truths they bring to birth have been discovered by themselves from within. But the delivery is heaven's work and mine. ${ }^{21}$

Porfiry's reference to "seed" (semia), the word with which he is frequently associated, brings to mind another instance of "seed": Brothers Karamazov's "seeds from other worlds," the divine seeds waiting for growth and delivery. By invoking this concept of "seed," Porfiry foregrounds his role as a spiritual

21 Theaetetus $150 \mathrm{~b}-\mathrm{c}(855)$. 
midwife. Zosima in Brothers Karamazov explains the concept in the following manner: "God took seeds from different worlds and sowed them on this earth, and His garden grew up and everything came up that could come up but what grows lives and is alive only through the feeling of its contact with other mysterious worlds. If that feeling grows weak or is destroyed in you, the heavenly growth will die away in you." 22

This concept of "spiritual seeds," to which Porfiry alludes during the second interview, gets further articulation in the final interview. Here we witness an altogether different Porfiry: he is now a somber and wise person, appealing to Raskolnikov's spiritual and religious values. The interview takes place in Raskolnikov's room, his home turf, so to speak. Here Porfiry does his best to level with Raskolnikov: he is serious, thoughtful, and sincere-as much as he can be. He no longer mocks or taunts Raskolnikov; he almost insists on being his peer. He claims to understand and appreciate Raskolnikov's soul and heart, his ambitions, his impatience, his nobility and idealism. It is exactly to these qualities that he appeals, and he insists that Raskolnikov is not the type who escapes and persists in his criminality while losing the ideology that can back him up. Consequently, Porfiry offers a different type of resolution: a voluntary confession rather that arrest and trial.

Porfiry argues that Raskolnikov would eventually ripen for the confession: "If I lock you up, you'll wait for a month or two, and then come with confession, unexpectedly to yourself" (352). In describing Raskolnikov's turmoil, and his "readiness" for the delivery, Porfiry resorts to the metaphors of pregnancy and birth: "I understand what it means to carry it all on yourself" (344). "To carry" (peretashchit') is a term that implies carrying a burden, as if during the pregnancy.

It is also important to stress that Raskolnikov enters the final interview with the very strong feeling of being closed in, of "needing fresh air." Having witnessed Mikolka's confession, and realizing that he has temporarily beaten Porfiry's suspicions, he feels trapped: "Until this, everything had been too oppressive and confining, had crushed him with its overwhelming weight, and a sort of stupefaction had descended on him. From the moment of the scene

22 Fyodor Dostoevsky, The Brothers Karamazov, trans. Richard Pevear and Larissa Volokhonsky (London: Vintage, 2004), 276. 
with Mikolka at Porfiry's, he had begun to feel suffocated and hemmed in, without escape" (376). On a metaphorical level, the gestation period is over: Raskolnikov has reached the moment when he wants to be caught and delivered from his old criminal self into a new one, and his readiness becomes obvious even to him (345).

Altogether, Porfiry mentions God and saints, invokes religious concepts, and refers to the Bible no less than fifteen times in this dialogue. At one moment, he asserts,

How much do you know? Seek and ye shall find. Perhaps it is through this that God seeks to bring you to himself... Perhaps you ought to thank God: how do you know that He is not sparing you just for that? Keep your heart high and don't be so fearful! Do you flinch from the great fulfillment that confronts you? No, that would be shameful ... I know you do not believe me, but it is the sacred truth that life will sustain you ... Now you need only air, air, air ... Who am I? I am a man who has developed as far as he is capable, that is all. A man, perhaps, of feeling and sympathy, of some knowledge, perhaps, but no longer capable of further development. But you - that's another matter: the life God destined you for lies before you ... Become a sun, and everybody will see you. The first duty of the sun is to be the sun. (389)

In a complex argument, Porfiry suggests that Raskolnikov has to return to himself first in order to return to God through becoming what God destined him to become. This transformation clearly implies not so much birth as rebirth. That's exactly what Socrates was striving to achieve through his communication with his various interlocutors. Describing Socrates's complex interaction with the youth, Edmonds writes,

On the one hand Socrates is ... the needy barefooted philosopher who is eternally seeking ... He seeks out beautiful youth, and engages them in conversations about the good life and virtue ... But Socrates is also Socrates the beautiful, ... whose outward ugliness hides supreme beauty ... This beauty serves as midwife to the thoughts of all the young men with whom Socrates consorts ... relieving them of the pains of their spiritual pregnancy and helping them actively pursue philosophy. Socrates plays the role of both lover and beloved in these relationships. ${ }^{23}$

23 Edmonds, "Socrates the Beautiful," 262. 
Indeed, the aesthetic dimension of Socrates's midwife activity is made explicit by Alcibiades. Alcibiades is very specific about Socrates's goal to educate, to induce the transformation, to bring out the best in men by acting as an aesthetic catalyst or magnet. By appealing to their ethical and aesthetic sense, by revealing his own inner beauty, Socrates makes them act in accordance with what is the best in them:

He loves to appear utterly uninformed and ignorant.—isn't that like Silenus ... Don't you see that it's just his outer casting, like those little figures I was telling you about. But believe me, friends and fellow drunks, you've only got to open him up and you'll find him so full of temperance and sobriety that you'll hardly believe your eyes ... He does not really care about a row of pins about good looks ... or money, or any of the honors that most people care about. $\mathrm{He}$ doesn't care a curse for anything of that kind, or for any of us either ... and he spends his whole life playing his little game of irony and laughing up his sleeve at all the world. I don't know whether anybody else has ever opened him up when he's been serious, and seen the little images inside, but I saw them once, and they looked so godlike, so golden, so beautiful and so utterly amazing that there was nothing for it but do exactly what he told me. ${ }^{24}$

One of the most important features of Socrates - according to Alcibiades — was his ability to provide his audience with moral education when they least expected it. By mocking and undermining their presuppositions, Socrates didn't just reveal the inadequacy of his interlocutors' reasoning, he clearly had a bigger fish to catch: encouraging moral growth and eventual delivery of a new self. Alcibiades's rhetoric and imagery describes the process in the following way:

Anyone listening to Socrates for the first time would find his arguments simply laughable: he wraps them up in just the kind of expressions you'd expect of such an insufferable satyr. He talks about pack asses and blacksmiths and shoemakers and tanners, and he always seems to be saying the same old thing in just the same old way, so that anyone who wasn't used to his style and wasn't very quick on the uptake would naturally take it for the most utter nonsense. But if you open up his arguments, and really get into the skin of them, you'll find that they're the only arguments in the world that have any sense at all, and that nobody else's are so godlike, so rich in images of virtue, or so peculiarly, so entirely pertinent to those inquiries that help the seeker on his way to the goal of true nobility. ${ }^{25}$

24 Symposium $216 \mathrm{~d}-\mathrm{e}, 217$ (568).

25 Symposium 221e-222a (572). 
Alcibiades continues, stressing Socrates's art of inducing his audience to recognize their erring ways, while provoking them to experience shame, to acknowledge their lost status, and to embark on restoration or improvement:

And then again, he reminds me of Marsyas the Satyr.

... And aren't you a piper as well? I should think you were-and a far more wonderful piper than Marsyas, who had only to put his flute to his lips to bewitch mankind. It can still be done, too, by anyone who can play the tunes he used to play. Why, there wasn't a note of Olympus' melodies that he hadn't learned from Marsyas. And whoever plays them ... the tunes will still have a magic power, and by virtue of their own divinity they will show which of us are fit subjects for divine initiation.

Now the only difference, Socrates, between you and Marsyas is that you can get just the same effect without any instrument at all—with nothing but a few simple words, not even poetry. Besides, when we listen to anyone else talking, however eloquent he is, we don't really care a damn what he says. But when we listen to you, or to someone else repeating what you've said, even if he puts it ever so badly ... we're absolutely staggered and bewitched....

But this latter-day Marsyas, here, has often left me in such a state of mind that I've felt I simply couldn't go on living the way I did. ... He makes me admit that while I'm spending my time on politics I am neglecting all the things that are crying for attention in myself. ${ }^{26}$

That is the trajectory that Raskolnikov himself seems to undertake, encouraged and helped by Porfiry, who, similar to Socrates, assumes the role of a midwife in Dostoevsky's text, of someone who brings forth what has already been inside of his patient. Furthermore, in true midwife fashion, Porfiry disappears by the end of the novel. (According to Russian folklore tradition, on the day of the birth, the midwives were supposed to arrive to and leave the house without being noticed. ${ }^{27}$ ) He made sure, however, that there is no "evidence" against Raskolnikov among the police documents, so that Raskolnikov's "unexpected” confession mitigated his sentence. Porfiry deliberately dismisses his own professional activity and accomplishment, only to

26 Symposium 215b-216a (566-67).

27 G. I. Kabakova, "Otets i povitukha v rodil'noi obriadnosti Poles'ia," in Rodiny, deti, povitukhi $v$ traditsiakh narodnoi kul'tury, ed. S. Neklyudov (Moscow, 2001), 109. 
help Raskolnikov on his path toward rebirth. The police investigator gives way to the spiritual midwife, thus fully assuming the role played by Socrates in his society. In a rather revealing gesture, Dostoevsky last refers to Porfiry when he mentions that Porfiry, along with Raskolnikov's doctor, Zosimov, attends Dunya and Razumikhin's wedding, an event more closely related to childbearing and rebirth than to criminal investigation.

\section{Conclusion}

It is interesting to observe that another literary masterpiece written at the time of Crime and Punishment-Tolstoy's War and Peace-also features a character who functions like a midwife, bringing forth everything that was gestated in Pierre Bezukhov's soul. I refer to Platon Karataev, another figure whose manners and appearance are compared to those of a peasant woman $(b a b a)$, and whose gestures - as he brings Pierre back to life-clearly invoke the gestures of a midwife.

In Tolstoy's rendering, we witness the collapse and then restructuring of Pierre, who has just witnessed the senseless execution of Russian prisoners during the French retreat from Moscow:

From the moment Pierre witnessed those horrifying murders committed by men who had no wish to commit them, it was as if the mainspring of his soul, on which everything depended and which made everything seem alive, had collapsed into a heap of meaningless rubbish. Though he was not even aware of it, his faith in the right ordering of the universe, in humanity, in his own soul and in God, had been destroyed ... Now he felt that through no fault of his own the world had crumbled before his eyes, and only meaningless ruins remained. He felt that it was not in his power to regain his faith in life. ${ }^{28}$

And yet, after experiencing this collapse, Pierre undergoes both physical and intellectual rebirth, assisted in this process by Platon Karataev, clearly a midwife figure:

Beside him, sitting in a stooped position was a little man whose presence made itself known to him by the strong smell of sweat that emanated from him every time he moved ... Having unwound a cord that was wrapped

28 Leo Tolstoy, War and Peace, trans. Ann Dunnigan (New York: Signet, 1968), 1156. 
around one leg, he carefully coiled it up, and, glancing at Pierre, immediately set to work on the other leg... In his way, with swift deft circular motions, one following the other without pause, he took off whatever things he was wearing on his feet and hung them on pegs in the wall overhead. Then he took out his knife and cut off something... Pierre was conscious of something pleasant, soothing, and complete in those deft, circular movements, in the man's well-ordered arrangements in his corner ... "Eh, don't fret, dear man," he said in the gentle, caressing, singsong voice in which old Russian peasant women talk. "Don't fret, friend; suffer an hour, live an age ... Here, have a bit of this, sir," he said, and ... untying the rag he handed Pierre several baked potatoes ... He took a potato, drew out his clasp knife, cut the potato into two equal parts on the palm of his hand, sprinkled some salt on them from the rag, and handed them to Pierre ... "You try 'em like that!" Pierre thought he had never tasted anything so delicious. "Oh, I am all right," he said, "but why did they shoot those poor fellows? The last one wasn't even twenty.” ... “Tsk, tsk, what a sin, what a sin!”... Sounds of screaming and shouting were heard somewhere in the distance, and the glare of the fire was visible through the cracks of the shed; but inside it was dark and quiet. Pierre didn't sleep for a long time, but lay with wide-open eyes listening to the rhythmic snoring of Platon, who lay beside him in the darkness, and he felt that the world that had been shattered was beginning to rise again in his soul, but with a new beauty, and on new, unshakable foundations. ${ }^{29}$ (all emphasis is mine)

It is a fascinating fact that both authors invoked a similar image of a midwife in two of their greatest novels written in the 1860s. The period of Great Reforms must have filled the authors and their public with heightened expectations when Russian society, long pregnant with reforms and modernization, was waiting for the delivery. In other words, the image of midwives was clearly in the air as the country was on the eve of transformation, waiting for a new society to emerge from the old one based on serfdom.

Both Raskolnikov's and Pierre's examples reveal a certain optimism, the hope that a positive transformation was possible, that a new protagonist can be delivered. The optimism was slightly dampened by the fact that in Tolstoy's novel, Prince Andrei's wife dies in childbirth. Yet, as a certain disillusionment with reforms had set in in the 1870s, we witness a different image of a midwife or even of child delivery. Anna Karenina, for example, is tormented by nightmares,

29 Ibid., 1156-60. 
in which she dies in childbirth. Furthermore, no new Anna emerges by the conclusion of the novel.

This issue becomes even more pronounced in Dostoevsky. In fact, the image of midwives, or failed child-deliveries, continues to haunt him, acquiring more and more negative and satirical connotations, as great expectations were giving way to lost illusions.

The Demons is rife with imagery of childbirth and midwifery, all of which go awry. It is therefore hardly surprising that in The Demons physical or spiritual beauty is mostly absent, and rationalism and violence defeat aesthetics. As Shatov's wife is getting ready to give birth she requests a traditional midwife. Instead, she is introduced to the modern-day radical akusherka, Virginskaya, who, despite her professionalism, delivers death, disharmony, and disintegration. The very fact that modern radicalsincluding young educated midwives-are disconnected from spirituality and beauty is highlighted by Kirillov: an ugly, clumsy, and self-destructive individual who can't even speak coherent Russian. Kirillov's emblematic failings are made obvious in this dialogue with Shatov, in which Shatov's grotesque masculine imbecility is matched by Kirillov's clumsiness and utter lack of coherence:

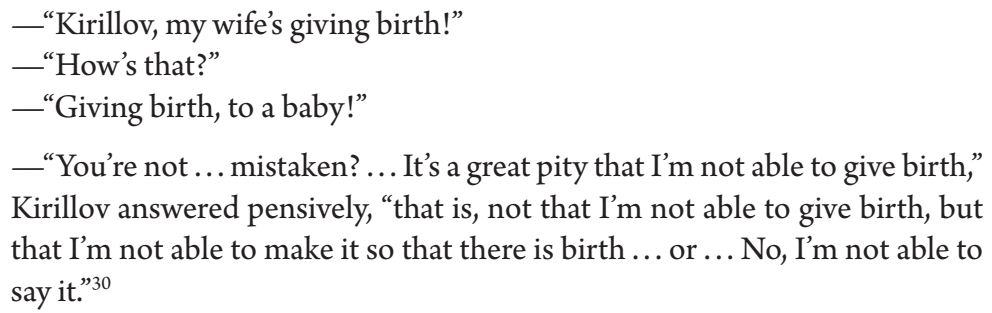

Although he is not able to say what is involved in "giving birth," Kirillov persists in belaboring, and eventually carrying out, his highly paradoxical and equally ugly theory of suicide.

Despite his ugly surroundings, Shatov is given a chance to glimpse the beauty and mystery of childbirth. In his rapture he declares to the radical midwife, Virginskaya, "The mystery of the appearance of a new being, a great mystery and an inexplicable one, Arina Prokhorovna, and what a pity you don't

30 Fyodor Dostoevsky, The Demons, trans. Richard Pevear and Larissa Volokhonsky (New York: Vintage, 1994), 581. 
understand it! ... There were two, and suddenly there's a third human being, a new spirit, whole, finished, such as doesn't come from human hands; a new thought and a new love, it's even frightening... And there's nothing higher in the world!"31

Virginskaya feels the instant need to drag this exaltation through the mud. She resorts to a cynically utilitarian retort by insisting that childbirth is only "the further development of the organism, there's nothing to it, no mystery ... That way every fly is a mystery. But I tell you what: unnecessary people shouldn't be born. First reforge everything so that they're not unnecessary and then give birth to them. Otherwise, you see, I've got to drag him to the orphanage tomorrow." 32

This refraction of the image of a midwife throughout Dostoevsky's oeuvre reveals that this topic was hardly accidental in Crime and Punishment. Dostoevsky's explorations of the mysteries of Russian cultural development, of its complex and contradictory search for rebirth, clearly unite his earlier and later novels. Numerous midwives, to whom Crime and Punishment alludes, appear in realized form in The Demons; yet, they no longer function in the mythical and ancient role of a spiritual midwife that goes back to Socrates. Instead, the stage is set for the modern, medically educated, yet spiritually nihilistic midwives and their stillborn children to preside over the scenes of murder and suicide.

31 Ibid., 593.

32 Ibid. 